\title{
Meta
}

Journal des traducteurs

Translators' Journal

\section{The Translating of Screenplays in the Mainland of China}

\section{Chunbai Zhang}

Volume 49, numéro 1, avril 2004

Traduction audiovisuelle

Audiovisual Translation

URI : https://id.erudit.org/iderudit/009033ar

DOI : https://doi.org/10.7202/009033ar

Aller au sommaire du numéro

Éditeur(s)

Les Presses de l'Université de Montréal

ISSN

0026-0452 (imprimé)

1492-1421 (numérique)

Découvrir la revue

Citer cet article

Zhang, C. (2004). The Translating of Screenplays in the Mainland of China. Meta, 49(1), 182-192. https://doi.org/10.7202/009033ar

\section{Résumé de l'article}

Le doublage des films et feuilletons télévisés sur le continent chinois est soumis à diverses contraintes : en plus de l'exigence élémentaire de la compréhensibilité immédiate et de la synchronisation entre images et son, il doit répondre à des exigences linguistiques, culturelles et politiques. Ces dernières limitent l'étrangéité des produits audiovisuels. Un certain nombre de stratégies de traduction telles que la traduction littérale, la traduction libre et l'omission sont présentées et discutées. Puisque l'un des principes de la traduction audiovisuelle est la recherche de l'effet équivalent, le traducteur doit s'efforcer de réduire les efforts de compréhension du spectateur. Enfin, selon l'auteur, à mesure que la distance culturelle entre la Chine et l'Occident se réduit, les éléments « exotiques » offerts par les films en version chinoise augmentent de plus en plus.
Ce document est protégé par la loi sur le droit d'auteur. L'utilisation des services d'Érudit (y compris la reproduction) est assujettie à sa politique d'utilisation que vous pouvez consulter en ligne.

https://apropos.erudit.org/fr/usagers/politique-dutilisation/ 


\title{
The Translating of Screenplays in the Mainland of China
}

\author{
CHUNBAI ZHANG \\ East China Normal University, Shanghai, China \\ wenda-c@online.sh.cn
}

\begin{abstract}
RÉSUMÉ
Le doublage des films et feuilletons télévisés sur le continent chinois est soumis à diverses contraintes: en plus de l'exigence élémentaire de la compréhensibilité immédiate et de la synchronisation entre images et son, il doit répondre à des exigences linguistiques, culturelles et politiques. Ces dernières limitent l'étrangéité des produits audiovisuels. Un certain nombre de stratégies de traduction telles que la traduction littérale, la traduction libre et l'omission sont présentées et discutées. Puisque l'un des principes de la traduction audiovisuelle est la recherche de l'effet équivalent, le traducteur doit s'efforcer de réduire les efforts de compréhension du spectateur. Enfin, selon l'auteur, à mesure que la distance culturelle entre la Chine et l'Occident se réduit, les éléments «exotiques» offerts par les films en version chinoise augmentent de plus en plus.
\end{abstract}

\section{ABSTRACT}

This essay discusses the translating of screenplays for dubbing in the mainland of China. It is shown that, besides the basic requirements of immediate comprehensibility and lip synchronization, the dubbing of foreign films and TV series into Chinese is subject to a number of linguistic, cultural and political constraints, which in turn put a limit on the "exotic" space in the dubbed films and TV series. A number of relevant translation strategies are then discussed, including literal translation, reduction of the original image to sense, and deletion. It is emphasized that since the basic principle of screen translation should be one of equivalent effect, the translator should endeavor to reduce the processing effort of the audience. Furthermore, it is pointed out that this "exotic" space has been increasing along with the narrowing of the cultural gap between China and the West.

\section{MOTS-CLÉS/KEYWORDS}

allusions, clichés, dubbing, equivalent effect, metaphors

In the mainland of China, most foreign films shown in cinemas are dubbed rather than subtitled. The Chinese translators and their colleagues have developed such fine skills that it often seems as if the dubbed films had originally been produced in Chinese. Few people, however, are aware of the numerous difficulties that the translators have to overcome and how much original flavour is lost while they admire the brilliant work of those dubbing actors and actresses. In this paper I will discuss some of the major constraints on the translating of screenplays from English into Chinese and the relevant strategies at the disposal of the translator. Such constraints may be cultural and political as well as linguistic in nature. In order to show the differences between the two languages, I will provide a literal back translation (abbreviated as "BT") of the Chinese version of each sentence. Hopefully my discussion will be able to throw some light on the permissible amount and nature of exotic elements on the Chinese screen. 


\section{The basic principle of screen translation}

It should perhaps be pointed out at the very outset that there is a great difference between a dialogue read silently and a dialogue read aloud. This is particularly true of the Chinese language, whose characters, unlike the alphabetic letters of Western languages, have a powerful visual impact on readers. Some combinations of characters, i.e. phrases and idioms, may look more beautiful or ugly than others to native speakers of Chinese. As elegance has been considered an important criterion of good translation in China, many critics still judge the quality of literary translation in terms of the translator's skill in using such phrases and idioms. Consequently, the dialogues in the Chinese versions of many English novels and short stories are meant to be read silently. They can be difficult to understand at first sight, but readers can reread them or even consult the dictionary if necessary. Such dialogues, if read aloud, might sound extremely unnatural or even incomprehensible to ordinary readers.

Film dialogues, on the other hand, are to be read aloud. They must be immediately comprehensible and natural to the native ear since what takes place on the screen is irreversible. The translator must resist the temptation of producing aesthetically satisfying dialogues like those printed on the page in works of serious literature for the simple reason that dubbed films should "preserve the same effect on the hearer that the original has in the source language." (Reiss, 2000: 46) According to Gutt (2000: 107), they should be translated "in such a manner that it yields the intended meaning without putting the audience to unnecessary processing effort." In other words, with rare exceptions, dubbed film dialogues must not be too difficult to understand at first hearing - since there is no second hearing. In most cases, the translator must see to it that the translated dialogues are comprehensible to most Chinese viewers with a minimum level of education or even those without any schooling such as some illiterate elderly people and preschool children.

\section{The synchronization of lip movements}

The synchronization of lip movements is perhaps a universal constraint on the dubbing of films in any country, since any well-dubbed film should not only enable the audience to follow what the speakers are saying but also indicate who is speaking on the screen. Without lip synchronization, the audience might be confused when, for instance, two characters are arguing about something. Besides, when a particular character is speaking, the target text has to pause where there is a pause in the source text, be it at the end of a sentence, a clause, a phrase, or even in the middle of a word when s/he is facing the camera. Sometimes it might be desirable to combine two sentences into one, provided that the target utterances are natural. For example: ${ }^{1}$

(1) Scott might take me, if I asked him...diplomatically. (- Two Marriages) 斯科特会带我去的, 只要我...巧妙些。

(BT: Scott might take me. If I did it...diplomatically.)

(2) Really? Well...huh... you know I can't just...tear up those letters...I mean, they really go to me...I...You sounded so alone. (- Two Marriages) 真的吗? 呃, 你知道......我看了那些信.......里很不好受......你好象很孤独。

(BT: Really? Huh...you know...I read those letters... and felt very sorry....You sounded very alone.) 
(3) I said my earrings are American. They are African...American. (- Philadelphia) 我说我的耳环是美国式的, 只是有点......非洲风格。

(BT: I said my earrings are American. Only they're of... African style.)

(4) Do me one honor. Put it on. (- The Colbys)

请你为我......穿上它。

(BT: Please [do it]for me...put it on.)

Sometimes, in order to make the target text sound natural to the audience, the translator must also try to match the shape of the speaker's mouth with corresponding sounds - an open vowel for an open vowel and a close vowel for a close vowel - when the camera is close on him or her, though they do not have to be exactly the same sounds. For example:

(5) Are you sure you've got the right bloke? (- Big Sky)

你能确定你们抓对人了? 2

(BT: Are you sure you've arrested the right guy?)

(6) - Shelby's dating now?

- Your daughter's growing up. (- Two Marriages)

--谢尔比谈恋爱了?

(BT: Shelby's dating now?)

--你女儿长大了。

(BT: Your daughter's growing up.)

Here in example (5) the Chinese characters 确定 (/que ding/) and 抓 (/zhua/) contain similar vowels to those of “sure" and “right" respectively; in example (6), 谈恋爱 (/tan lian ai/) and 长大 (/ zhang da/) are similar to "dating" and "growing up" in pronunciation.

Needless to say, the translator has more freedom if the camera is not close on the speaker. For example:

(7) I see you deserve a ... tea. (- The Consul)

我请你去喝杯...茶。

(BT: I'd like to invite you to...tea.)

(8) Then you threw on some rags and taxied right over with ink all over your fingers. (- A Man Called Hawk)

然后你随便套了件衣服, 连手也没洗, 就打的过来了。

(BT: Then you threw on a coat and taxied right here without even washing your hands.

Here in example (7) the Chinese character for "tea" is pronounced as /cha/, which contains an open vowel, whereas the English "tea" contains a close vowel /i:/. In example (8), the word order is adjusted. The last few characters, i.e. “打的过来了” (BT: taxied right over, pronounced as /da di guo lai le/) do not match the English phrase "with ink all over your finger" either. The whole sentence does not even have the same pauses as those in the original. All these are justifiable since the camera is not close on the speakers.

\section{The matching of gestures}

Related to the synchronization of the speaker's lip movements is the matching of the speakers' gestures. Due to the linguistic and cultural differences between English and 
Chinese, we sometimes have different word orders and even different gestures for the same meaning. In such cases, normally the "picture" on the screen prevails. For instance, in Chinese when the pronouns 'I,' 'you' and 's/he,' or 'we, 'you' and 'they' are used together, normally the first person pronoun comes first, and the third person pronoun comes last, while in English the first person pronoun comes last. So in Chinese we normally say “我, 你, 他/她 (I, you and s/he)," and “我们, 你们, 他们 (we, you and they)," while English speakers normally say "you, s/he, and I" and "you, they, and we." The reason behind all this may well be cultural. My speculation is that the Chinese speaker tends to assume the center of the conversation, while in English more "face" is given to the addressee, but this speculation still needs to be proved. Another typical example is the translation of the English negative word "No" in response to questions like "You're not a teacher, are you?" In Chinese, the negative answer “No. I'm not” is expressed as “是的, 我不是” (BT: Yes. I'm not.). So while an English speaker would shake his/her head when uttering the sentence, a Chinese speaker would nod his/her head. In such circumstances, the translator has to follow the screen. In the former case, if the speaker first points at the hearer and then at himself/herself while saying "You and I...," the translator will have to translate it as “你和我” (you and I). In the latter case, when the speaker says “No. I'm not" while shaking his/her head, he will have to translate it into “不, 我不是” (BT: “No. I'm not.”) - in violation of the linguistic convention of the target language. For example:

(9) It's just you... and me. (- The Colbys) [points at the addressee and himself respectively when uttering "you" and "me"]

这儿只有你.......和我。

(BT: Here are only you....and me.)

(10) - So we shouldn't rule out murder.

- No. [shakes his head]

-- 因此不能排除他杀。

(BT: So we shouldn't rule out murder.)

-- 不能。3

(BT: No.)

(11) This uh...this next number is uh...is a wedding gift...to the beautiful lady...who will be kind enough to marry me this Saturday, Miss Shelby Coles. (- The Wedding) 下面......这首曲子是....... 一份结婚礼物.......献给一位美丽的姑娘。她就是将于 本周六和我结婚的......谢尔比.科尔斯小姐。 4

(BT: The following...piece of music is... a wedding gift...to a beautiful lady. She is marrying me this Saturday - Miss Shelby Coles.)

Here the target versions of examples (9) and (10) obviously deviate from the Chinese convention but they will not cause any misunderstanding since they are accompanied by relevant gestures.

Similarly, according to the normal word order in Chinese, example (11) should be translated as:

\section{下面......这首曲子是......献给本周六将和我结婚的一位美丽的姑娘一一谢尔比.科尔斯 小姐的一份结婚礼物。}

(BT: The following...piece of music is...for the beautiful lady who is marrying me this Saturday - Miss Shelby Coles as a wedding gift.).

The target version here has to follow the original word order because the speaker points at the lady at the end of the sentence. 


\section{Cultural constraints and the translation of cultural items}

Another constraint has to do with cultural items, which are pervasive in many films and TV series, especially the numerous allusions that sound "strange" to the Chinese audience. Such cultural items include certain proper names and words and phrases with religious and sexual allusions, as well as certain culture-specific metaphors, which often militate against transference and literal translation.

\subsection{Proper names}

Many personal names and other proper names that are familiar to Western people, for instance, may have to be normalised:

(12) ...tellin' some stories about her childhood doesn't make her Mata Hari. (- Flamingo Road) 即使关于她童年的故事是假的又有什么?

(BT: What does it matter even if her stories about her childhood were not true?)

(13) Was Camille so lovely...even on her deathbed? (- The Colbys)

天上的仙女临终时....... 有这么美吗?

(BT: Can even a fairy be so lovely...even on her deathbed?)

(14) We were...in love. We used to meet in secret...It was like Gone with the Wind, but there was no tomorrow.

我们…相爱了。常常秘密幽会, 可不久便分手了, 一切烟消云散。

(BT: We were...in love. (We) Often meet in secret...But we parted soon, and everything vanished like smoke and clouds. Note: "to vanish like smoke and clouds" is a cliché idiom in Chinese.)

Here "Mata Hari" and "Camille" are reduced to senses as they are unfamiliar to most Chinese people. Similarly, "Gone with the Wind" is rendered as "vanished like smoke and clouds" because, due to the basic requirement of immediate comprehensibility, it is impossible to preserve the pun. The Chinese audience would not be able to take the hint even if the Chinese translation of the book title???(BT: Fleeting Away) were embedded in the target sentence here. Such under-translations, therefore, seem to be unavoidable. This, of course, does not mean that all proper names are to be translated in this way. More familiar names such as "Elizabeth Taylor" and "Michael Jordon" are almost always transferred. In fact, the increasing exposure to Western cultures is rapidly narrowing this gap. What was totally strange to the Chinese people one or two decades ago may be as familiar to them today as anything around them.

\subsection{Sexuality}

Another notorious circumstance has to do with sexuality. While in the West people can discuss sex candidly, few Chinese people can talk about it without a blush. In fact, it is sort of taboo to make explicit mention of sex in the Chinese culture. It is only too natural that four-letter words are used much more sparingly in Chinese films than in some of Hollywood films. In translating such films, the translator normally has to tone down or even delete such words. For example: 
(15) - Only four inches?

- You'll feel me. (- Long Kiss Goodnight)

--只有四英吋?

(BT: Only four inches?)

--够你受的了。

(BT: Enough for you.)

(16) (What the hell are you going to do for me? If you want to do something, you can pay the hospital bill. The hooker's union doesn't have a group medical plan! You don't want any favors! I'll pay you back - cash or trade, whatever you want.) I have my body. When it is back in working order, you can have your shot at it.

我有个身体, 等它能干活的时候, 就可以跟你上床。 ${ }^{5}$

(BT: I have a body. When it is able to work again, I can go to bed with you.)

Example (15) is a dialogue between the heroine and the antagonist, a killer who is going to attack her with a dagger in his hand. Here "only four inches?" is a pun hinting at his male organ, which is made more explicit by the answer "you'll feel me." In the translation, however, the pronoun "me" is deleted though it remains a pun - a more implicit one, which is an effort to avoid more direct reference to their sexual organs. In example (16), "you can have your shot at it" is toned down to the equivalent of a neutral "go to bed" since a literal translation would be distasteful to the Chinese audience.

The following examples are cited from an American film Erin Brockovich with Hong Kong subtitles and what I envisage would be their dubbed versions in the mainland of China, which might be of interest to Western readers:

(17) That ass-hole smashed in my fucking neck.

HK subtitle: 那个王八蛋撞上了我他妈的脖子。

(BT: That bastard smashed in my fucking neck.)

Mainland dubbing: 那个王八蛋撞上了我的脖子。

(BT: That bastard smashed in my neck.)

(18) - What're you yelling at me for?

- Because I'm pissed off!

- Good!

- Fuck you!

- Fuck you back!

HK subtitle: 一你干吗吼我? (BT: Why are you yelling at me)

一因为我不狶。(BT: Because I'm [sexually] not satisfied.)

一很好。(BT: Very good!)

一干你! (BT: Fuck you!)

一回干你！(BT: Fuck you back!)

Mainland dubbing: 一你嘲我吼什么? (BT: Why are you yelling at me?)

一我心里烦。(BT: I’m upset.)

一太好了! (BT: Great!)

一见你的鬼! (BT: Damn you!)

一见你的鬼! (BT: Damn you!)

From these examples we can see that Hong Kong translators seem to be bolder than their Mainland colleagues. On the other hand, it is clearly indicative of the fact that the Mainland people are more conservative about sexuality. The exotic space allowed for the other, after all, is subject to the conditions of the receiving culture. 


\subsection{Religious terms}

Religious terms may also present a great difficulty to translators of films. While almost everyone knows such names as "God" and "Bible," most Chinese people have a very limited knowledge of Christianity and other religions. They may have heard of "the Ten Commandments," but they probably do not know what "the Seventh Commandment" refers to. Therefore, in many contexts, sentences like "He has violated the Seventh Commandment" will have to be made explicit at the expense of the exotic flavor. Similarly, while "God” is translated creatively and authoritatively as “上帝”, other less familiar terms may have to be replaced by more general terms. For example:

(19) Who would believe...that the Evil One has already...found in her a servant and agent? Yet such, I grieve to say, is the case. (- Jane Eyre)

谁又会相信, 魔鬼已经附身于她, 她成了魔鬼的化身了? 而遗憾的是, 这的确 是个事实。6

(BT: Who would believe...that she is possessed by a devil and has in fact become its embodiment? Regrettably, this is the case.)

Here "the Evil One" has definite specific reference whereas its Chinese translation does not. That is why in the back translation, "a devil" is not capitalized.

\subsection{Metaphors}

Metaphors, along the lines of Newmark (1988: 105), can be classified into three types, viz. universal, original and cultural metaphors. While universal metaphors such as “a hell on earth (人间地狱 )” and “Walls have ears (隔墙有耳)” can be easily translated, original and cultural metaphors may present great difficulty to the translator. According to him (ibid.112), such metaphors in works of serious literature should be translated literally in order to keep the exotic flavor. This is, of course, desirable and often possible in screen translation, although some adjustments might be necessary. For example:

(20) Since then fortune has knocked me about, and kneaded me with her knuckles, and now I flatter myself I am hard and tough as an Indian rubber ball, with perhaps one small sensitive point in the middle of the lump. (- Jane Eyre)

然而, 命运却在捉弄我, 就像......㕪, 把一个橡皮球给弄硬了一样, 但是还保 留着球心那柔软的部分

(BT: But fortune has knocked me about, like...making a rubber-ball hard, but the heart of the ball is still soft.)

(21) Mom thinks I'm on the verge of womanhood and she can't wait to push me out of the cocoon and turn me into a social butterfly. (- Two Marriages)

我妈妈把我当做快要成熟的蚛蛾, 迫不及待地要把我推出蚕茧, 飞向成人的生 活

(BT: Mom thinks I'm a maturing moth, and she can't wait to push me out of the cocoon and force me to fly into the world of adults.)

(22) You're right. Along come someone else and wrecks a solid relationship. (- Love at First Sight)

是啊。第三者一出现, 爱情之舟马上触礁。

(BT: You're right. The boat of love is wrecked as soon as the third party appears.) 
In example (20) the dominant metaphor of a rubber ball is preserved, but the images of a lady kneading it with her knuckles is lost. This is mainly because there is not enough space for so many words. In examples (21) and (22), the images of the "cocoon" and "wreck" are preserved, but the implied images of the "moth" and "boat of love" are added respectively in order to supply the "missing link" and make the metaphors more acceptable to the target audience. Sometimes, however, it is more difficult or even impossible to keep the original images. In such cases, the translator might have to replace them with other metaphors, to normalize or even delete them for the sake of pragmatic force. In example (21) the image of the "butterfly" is deleted because the image of a "social butterfly" is not acceptable in Chinese. The following examples also illustrate this point:

(23) You wanted blood and you got it. (- The Colbys)

你不要太平, 你如愿了。

(BT: You didn't want peace and you got what you wished.)

(24) Memories are wonderful....and the good ones...stick to you like glue. (- Jessie) 回忆是美好的, 而美好的回忆......将伴你终身。

(BT: Memories are wonderful, and the good ones...stay with you all your life.)

(25) Sometimes I have a queer feeling with regard to you - especially when you are near me, as now: it is as if I had a string somewhere under my ribs, tightly and inexplicably knotted to a similar string situated in the corresponding quarter of your little frame. (- Jane Eyre)

我有时候......对你有一种奇怪的感觉。当你在我身边的时候, 我就感觉到.....

我的心......和你的心......完全......完全联系在一起了, 紧紧地连在一起了。

(BT: Sometimes I have a queer feeling about you. When you are near me, I feel...my heart... and your heart... are connected...completely intertwined, closely intertwined together.)

(26) You're fishing in the air. It's no use. (-Big Sky)

这是水中拹月, 没有用的。

(BT: You're fishing the moon in the water. It's no use.)

In examples (23) and (24), literal translations of "blood" and "glue" would have been extremely awkward and even incomprehensible. Similarly, the images of a "string" under a man's "ribs" "knotted" to another person's "string" in example (25) is a very strange image to the Chinese audience. The metaphor is therefore replaced by a cliché metaphor in Chinese - two hearts being closely connected to each other. For the same reason, the English metaphor "fishing in the air" in example (26) is replaced by the cliché Chinese metaphor "fishing the moon in the water." All these are justifiable attempts at making the dubbed films immediately comprehensible so as to produce the desired equivalent effect.

\section{Political constraints}

At this juncture, it might be necessary to correct a misconception in the West about the political constraints on the dubbing of films in China. Bassnett (1998), for instance, says that foreign films are dubbed instead of being subtitled in countries like China because their governments do not want the audience to hear "the original voices." This is at least not true of China. In fact, it is mainly for the sake of the audience that foreign films are dubbed rather than subtitled in China. Qian (2001) 
lists five reasons why dubbing is done in preference to subtitling in China. Two of them, in my opinion, are especially relevant: the poor foreign language level of most people in the country on the one hand, and the large percentage of "illiterate" and "semi-literate" population on the other. A pitiably small percentage - most probably even less than one per cent - of the Chinese population can enjoy English films in the original, since even English majors in universities and college still find it difficult to understand them. Only fairly well-educated people, who are mostly of the young generation between 18 and 30 in big cities, may be able to enjoy subtitled foreign films, though many of them still prefer dubbed films.

Another convincing piece of evidence against this misconception is the fact that, in the last decade or so, a number of institutions such as the China Central Television (CCTV) and Shanghai Television (STV) have initiated a number of foreign language programs and have even set up their own English channels. These programs and channels show subtitled foreign films and TV series regularly to the public. This seems to be a significant indication of the rapid changes of a society in the process of opening itself up to the outside world.

This, of course, does not mean that there are no political constraints on the dubbing of films in China. As far as I can see, such constraints are most strongly imposed on the selection of the films to be dubbed, which may be called pre-dubbing censorship. In China, such constraints are not so much on how the films are to be presented as on what to present to the public. There are, so to speak, two kinds of censorship, i.e. pre-dubbing censorship and post-dubbing censorship, the former being the selection of films to be dubbed and the latter being the examination of dubbed films. A brief look at the Chinese screen since 1949 shows that dubbed films have always been a most vivid reflection of the political mood of the time. In the 1950s, the only "foreign" films were from the former Soviet Union and other East European countries, which were mostly about the Russian revolution and the Second World War. In the early 1960s, after China broke up with the Soviet Union, only a very small number of Russian films were still being shown, such as Lenin in October and Lenin in 1918. A few years later, that is, in the late 60s and early 70s, China began to import films from other socialist countries, including Albania, Yugoslavia, and North Korea, which were more sympathetic with China. Films from non-Socialist countries were scanty and often symbolic of their relationship with China then when, for instance, it was necessary to create a friendly atmosphere for the official visit of the head of state of a country. In the late 1970s and early 1980s, when the policy of reform and opening to the outside world was adopted, American and West European films and TV series began to find their way into the country. However, at first those films were shown only to government officials and certain small academic circles. It was not until the second half of the 1980s that Western films and TV series began to be imported in substantial numbers. More and more special TV programs were set up for foreign films and TV series to satisfy the thirst of the Chinese public for anything foreign. A typical example is the American TV series Hunter dubbed and shown by the Shanghai TV Station (STV) in 1987 and 1988. The streets were simply empty and shops had almost no business when it was being shown; and it was sure to be a hot topic of conversation in factories, schools, and even on buses the next day.

In addition to the sources of films and TV series, there were also numerous other restrictions. The influence of the government over such matters is mainly exer- 
cised through the China Film Distribution Company - the sole institution that is authorized to import foreign films. The Company decides not only from which countries films should be imported but also which individual films can be imported. Its criteria seem to be both political and cultural. Politically, those films to be imported must not be anti-China and anti-Communist; culturally, they must not contain religious propaganda, pornography, or violence. In practice, however, the sternest cultural restriction seems to be on religious matters: virtually no films that preach Christianity or other religions have ever been imported since 1949. On the matter of sexuality, we can perceive an obvious process of change. Even in the 1980s and early 1990s, any kissing scene on the screen would cause quite a sensation within the audience, but today Chinese films themselves are beginning to surpass their Western peers. However, nudity is still considered pornography, and such scenes are normally either cut or shortened in the film-dubbing process. The translator, as was mentioned above, has to tone down such sexually explicit linguistic materials. This, however, is at the discretion of the translator himself and the director - according to their judgment of what is appropriate and what is not. And this seems to be a purely cultural issue. Most people have a good intuition about our cultural bottom line regarding sexuality. As regards violence, it may puzzle Westerners that what is considered violence to them is often disregarded in China. With the exception of horror films and those films with really bloody scenes, which are not imported, there are almost no actual restrictions on violence. Culturally, this might be due to the influence of Chinese kongfu, for compared with those kongfu films most Western films seem to be rather banal.

It may be necessary to add here that there is no system of categorization for films and TV series. Consequently, the Chinese screen is full of inappropriate materials, especially for children.

Compared with the pre-dubbing censorship, China's post-dubbing censorship on films and TV series is much less strict than is imagined in the West. Normally this is done by some people designated by the dubbing institutions, whose job is to examine whether there are still any politically inappropriate materials. This job seems to be symbolic since normally what should be done has already been done. My personal experience may serve as a good example. As a freelance screen translator, I have translated over 200 films and episodes of TV series in the past 18 years, but only one of them was banned by post-dubbing censorship. It was the film Philadelphia, which I translated for STV in the mid-1990s. I was told later that it was banned because it had to do with AIDS - which was still a sensitive topic then.

It should perhaps be mentioned here that, although politically "reactionary" films and TV series are banned in China, those individual films which are imported into the country may still contain politically inappropriate utterances which the translator must remove in the translating process. For instance, in a film about espionage activities between the West and Russia, a character may suddenly use very unfriendly words about China or curse Communism. In such cases, the translator will have to delete them or replace them with politically acceptable words. The "receiving pole" (Alvarez \& Vidal, 1996: 76) after all, dictates both what and how to translate, since translating is "culture bound" (ibid. 2). 


\section{Conclusion}

This paper shows that the translating of screenplays into Chinese is subject to a number of linguistic, cultural, and political constraints and that the translator has a number strategies at his disposal. It is emphasized that the translator's task is, together with his colleagues, to preserve the same effect on the target audience as in the source language by overcoming those barriers. Moreover, with the opening up of China to the outside world, what used to be "foreign" may sound perfectly natural to the Chinese audience today or tomorrow. Thus, while his translation strategies are dictated by the receiving culture, this culture itself is being altered by what he translates. Translating, in the final analysis, is a two-way operation that narrows the distance between the source and receiving poles.

\section{NOTES}

1. All the examples here, unless otherwise noted, are taken from films or TV series translated by me.

2. This episode of the TV series is translated by a student of mine.

3. See Zhao, 2002.

4. See Qian, 2001.

5. See Qian, 2002.

6. The examples from Jane Eyre in this paper are taken from a DVD edition of the dubbed film. The translator's name is unclear.

\section{REFERENCES}

Alvarez, R. \& M. Carmen-Africa Vidal (eds.) (1996): Translation, Power, Subversion, Clevedon: Multilingual Matters.

Bassnett, S. (1998): “The Translation Turn in Cultural Studies," Susan Bassnett, S. and A. Lefevere (1998): Constructing Cultures: Essays on Literary Translation, pp. 123-140. Clevedon: Multilingual Matters.

Gutt, E.-A. (2000): Translation and Relevance: Cognition and Context, Manchester: St. Jerome Publishing. Newmark, P. (1988): A Textbook of Translation, New York: Prentice Hall.

Qian, S. (2001): “Screen Translation in Mainland China - Past and Present," paper given at the International Conference on Dubbing and Subtitling in a World Context (18.10.2001), The Chinese University of Hong Kong. Published in this volume.

Reiss, K. (2000): Translation Criticism - The Potentials \& Limitations, Manchester: St. Jerome Publishing.

Zнао, C. (2002): “Translation into Chinese of Film Scripts and Scripts of TV Drama Series - Four Main Conflicting Demands," Chinese Translators Journal 32 (4), pp. 49-51. 